\title{
Management of regional odontodysplasia: a 10-year-follow-up case report and literature review
}

The aim of this article was to review the literature and present a case of regional odontodysplasia (ROD) with special emphasis on clinical and radiographic features. A 6-year-old girl was referred to our department with the chief complaint of missing her permanent maxillary left central incisor, lateral incisor, and both of her canines. The gingiva of the involved region was enlarged, fibrous, and tense. Radiographic examination showed abnormal tooth formation and shortened roots. After 3 years of follow up with temporary prosthetic rehabilitation, periodontal surgery was performed. Following forced eruption and levelling, abnormal tooth eruption and root development were observed. ProRoot MTA (Dentsply-Maillefer, Ballaigues, Switzerland) was used for root canal treatment. Intracanal fiber posts selected and access cavities were restored with composite resin. Prosthetic rehabilitation was completed with zirconia ceramic crowns. The time of diagnosis, characteristics of the present/existing symptoms, and functional and esthetic needs of the patient should be considered to determine the optimal treatment modality for ROD.

Keywords: Odontodysplasia; ghost teeth; tooth eruption; shell teeth; developmental anomaly

\section{Introduction}

Regional odontodysplasia (ROD) is first described by Hitchin (1) in 1934. ROD can also be defined as ghost teeth, nonhereditary amelogenesis imperfecta, odontogenesis imperfecta, and odontogenic dysplasia (2). ROD is a rare and unique dental abnormality that involves enamel, dentin, pulp, and follicle of both primary and permanent dentitions, generally affecting the teeth of one quadrant (3-6).

Diagnosis of this nonhereditary disorder is made by clinical as well as radiographic examination and, occasionally, supported with microscopic examination of the affected teeth $(1,2)$. An irregular surface contour with pitting and grooves is observed in the affected teeth during clinical examination $(2,5-7)$. The affected teeth appear hypoplastic and hypocalcified (3). These teeth also show extreme erosion and underlying periapical abscesses, with discoloring to yellow, or even yellowish brown. Radiographs display these teeth with having large pulp spaces and short roots with open apices. Due to lack of contrast between enamel and dentin tissues, the ROD tooth appears ghost-like. Eruption of the affected teeth is delayed or may not occur (1-10). Generally, affected permanent teeth replace affected primary teeth; however, normal permanent teeth may also replace affected primary teeth (5).

There are histological alterations present in ROD. Enamel structure is hypoplastic and hypocalcified, with changing thickness and uneven surfaces. Enamel prisms are randomly distributed, possibly including aprismatic regions with degenerated globular calcifications. Another common feature

\author{
Mine Koruyucu', \\ Duygu Yaman', \\ Figen Seymen', \\ Korkud Demirel' ${ }^{2}$, (D) \\ Koray Gençay ${ }^{1}$ (i)
}

ORCID IDs of the authors: M.K. 0000-0002-2077-5095; D.Y. 0000-0002-5974-1335; F.S. 0000-0001-7010-2035; K.D. 0000-0001-5904-8314; K.G. 0000-0002-9628-0099.

'Department of Pedodontics, Istanbul University Faculty of Dentistry, Istanbul, Turkey

${ }^{2}$ Department of Periodontics, Istanbul University Faculty of Dentistry, Istanbul, Turkey

This case report has been presented at the International Congress of Mediterranean Societies of Pediatric Dentistry and $21^{\text {st }}$ Congress of Turkish Society of Pediatric Dentistry (November 13-15, 2014, İstanbul, Turkey)

Corresponding Author: Mine Koruyucu E-mail: mine.yildirim@istanbul.edu.tr

Received: 12 September 2017 Revised: 28 October 2017 Accepted: 21 November 2017 DOI: 10.26650/eor.2018.495 
of ROD includes the presence of different degrees of pulpal calcification. Reduction of the dentin layer yields randomly distributed tubules that are lesser in amount. Extensive interglobular and amorphous dentin areas, predentin layer enlargement, and clefts, which might enable the pulp and oral cavity to communicate, were additional characteristics observed. Dense fibrous connective tissue constructs the dental follicle, which might demonstrate calcification areas (2-4, 8, $9,11)$. The affected enamel has been detected to have more mineral content than dentin in microradiographic studies (9).

The prevalence of this condition is still not clear since the literature have mainly been based upon case reports $(1,4)$. Males have been less affected than females. The mandible has been less frequently affected than maxilla (ratio, 1.6:1). The condition is usually unilateral, rarely crosses the midline, and is more common in the anterior dentition. Teeth may be affected in different degrees, even in the same arch. A tooth's inability to erupt has been the most distinctive clinical symptom of $\operatorname{ROD}(1,2,4,6,9,10)$.

The etiology of ROD is unknown. Various assumptions such as local circulatory disorders, viral infections, teratogenic drugs, neural crest cell defects, vascular defects, irradiation, Rh incompatibility, local trauma, local somatic mutation, hypophosphatasia, hypocalcemia, hyperpyrexia, nutritional deficiency, circulatory disorders, and idiopathic factors have been discussed (1, 2, 4, 9, 11, 12). Systemic anomalies, like facial asymmetry, may be present in some patients (9). In addition, this anomaly has been found to be associated with hemangioma, epidermal nevus, vascular nevi, ectodermal dysplasia, hydrocephalus, hypophosphatasia, and gingival swelling (2,
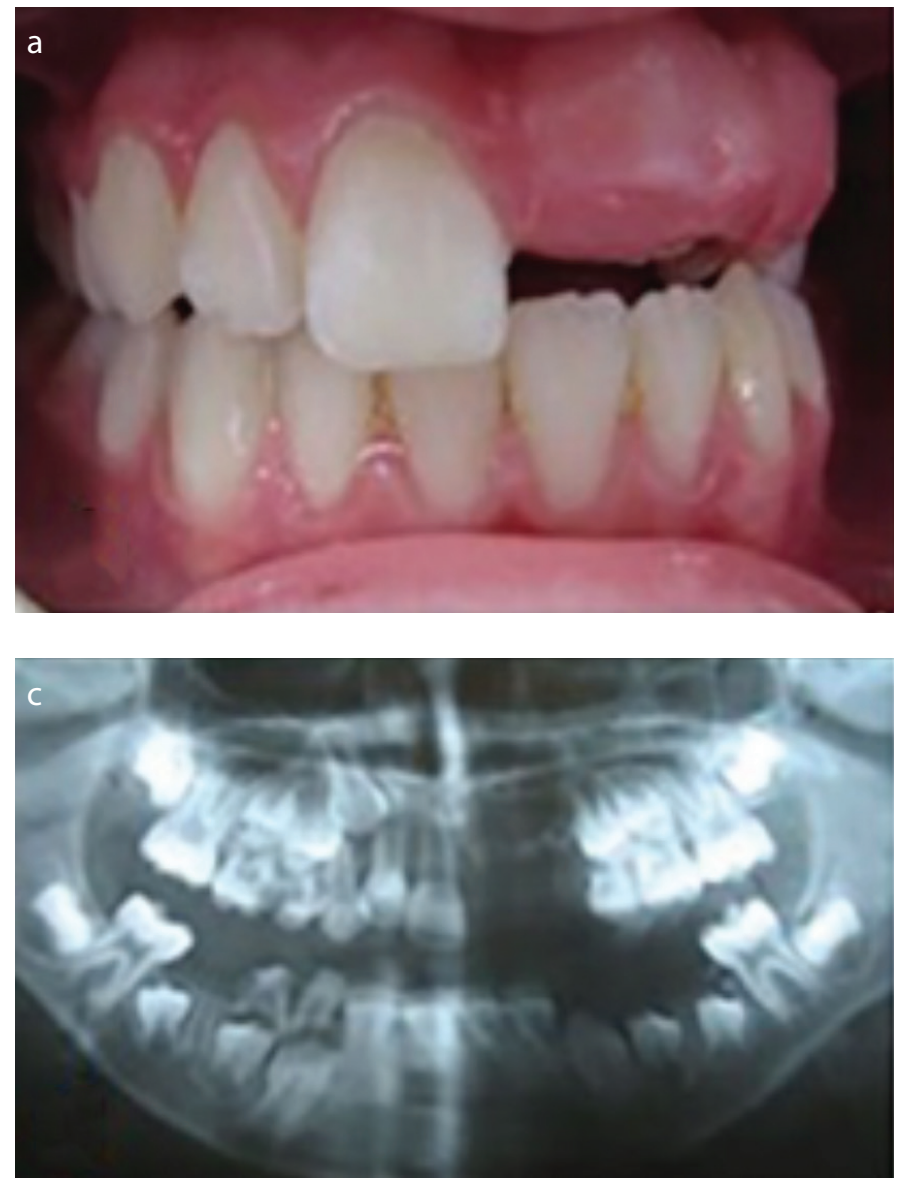

11). As Courson et al. (13) stated, there may be a link between odontodysplastic changes and metalloproteinases (MMPs), besides their inhibitors (TIMPs), in relation to ROD.

Regional odontodysplasia may be a separate syndrome or a symptom of oculodentodigital syndrome or epidermal nevus/Schimmelpenning-Feuerstein-Mims syndrome (7). A differential diagnosis of ROD includes hereditary conditions, such as dentin dysplasia, dentinogenesis imperfecta, amelogenesis imperfecta, oculodentodigital dysplasia, segmental odontomaxillary dysplasia, odonto-onycho-dermal dysplasia, or odontochondrodysplasia $(1,6)$.

The aim of this paper was to review the literature, present a case of regional odontodysplasia, and to discuss the clinical and radiographic characteristics and treatment of odontodysplasia.

\section{Case report}

In 2007, a 6-year-old girl was referred to İstanbul University Faculty of Dentistry Department of Pedodontics with the chief complaint of a missing or unerupted permanent maxillary left central incisor, lateral incisor and both canines.

There was no previous history of dental anomalies in either parent and no similar cases among family members. Her prenatal, natal, and medical history was unremarkable. Family is nonconsanguineous. The mother of the patient had a natural pregnancy and childbirth. The patient's past and medical history were not significant for any systemic abnormalities. When she was 18 months old, the patient fell on the left side of her face causing trauma. No history of previous extraction was seen in
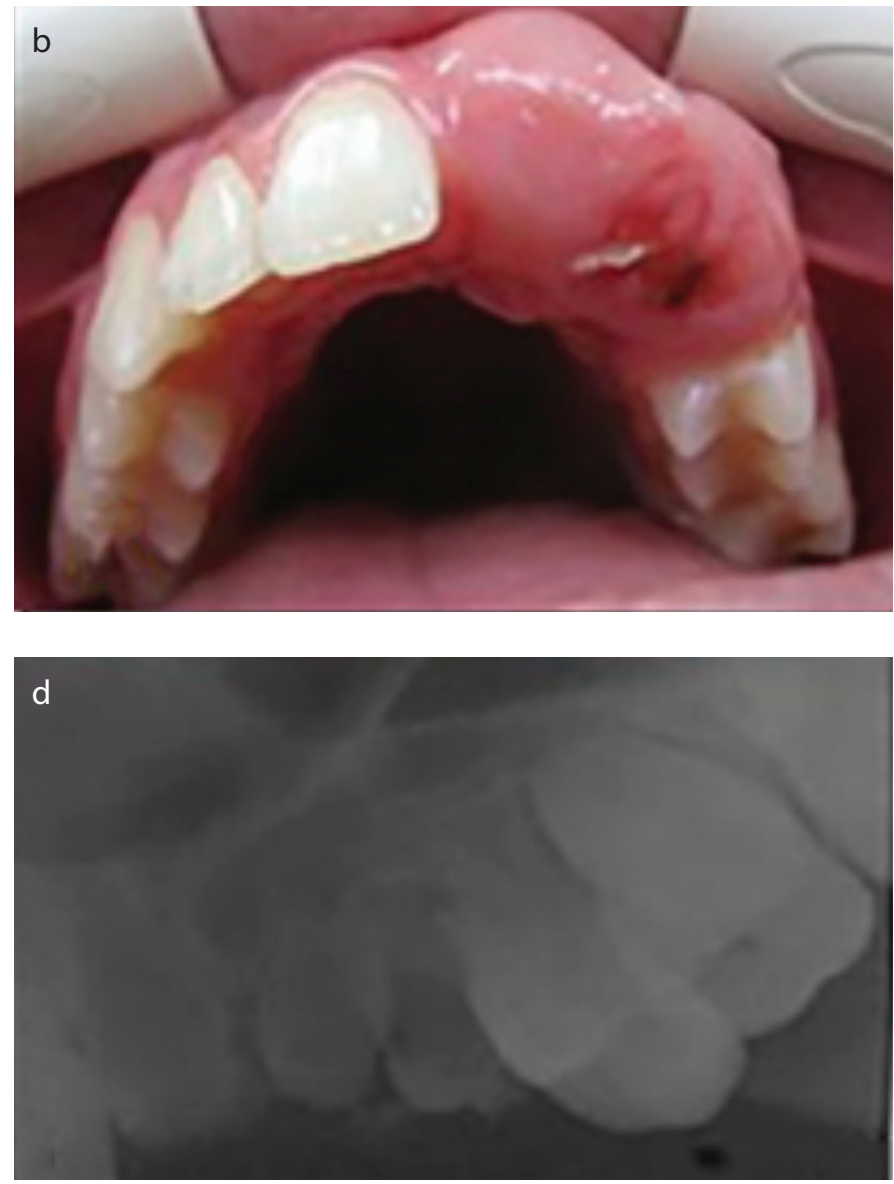

Figure 1. a-d. $(a, b)$ Intraoral (c, d) radiographic view during the first presentation. 

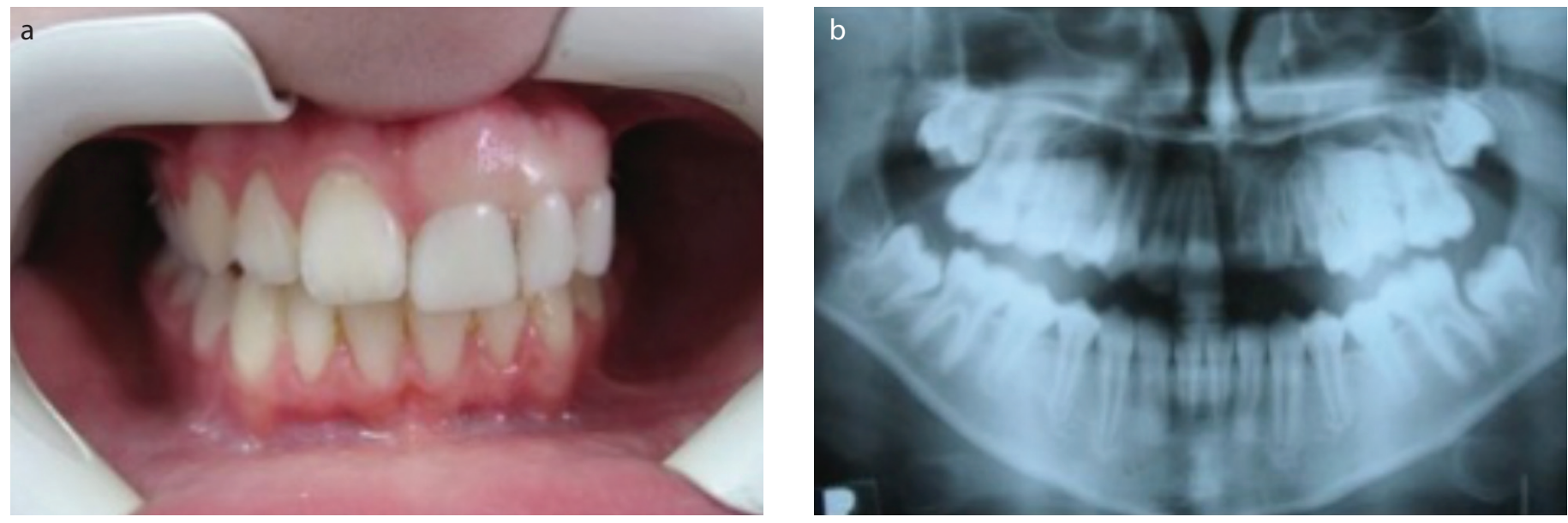

Figure 2. a, b. (a) Temporary prosthetic rehabilitation (b) 1 year follow-up panoramic radiograph.
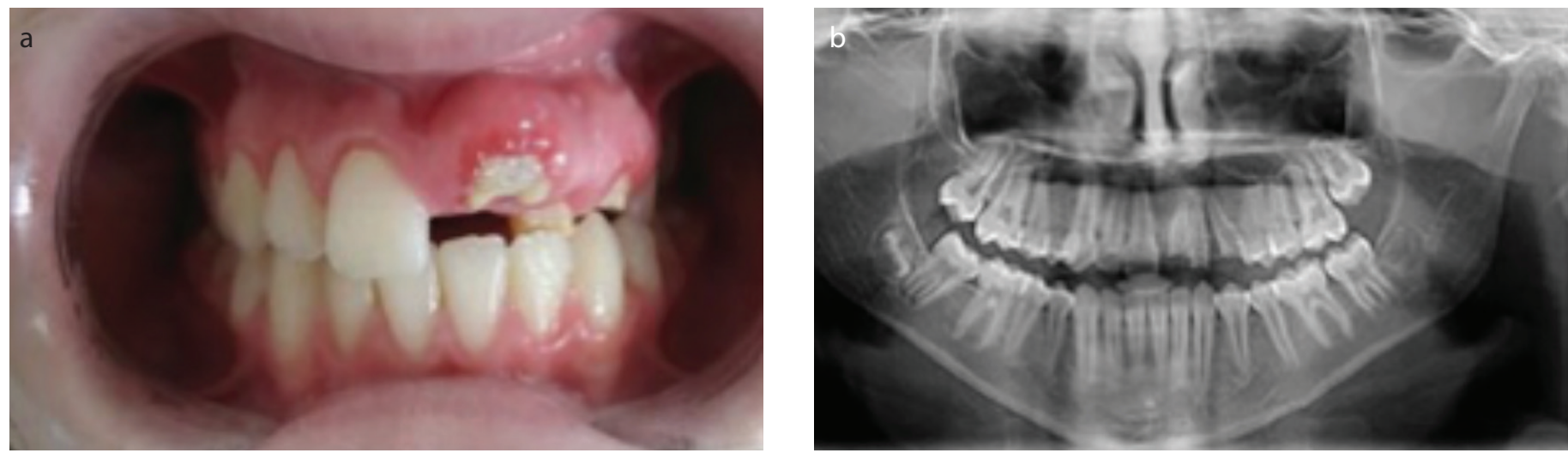

Figure 3. a, b. (a) Intraoral (b) radiographic view after periodontal surgery.
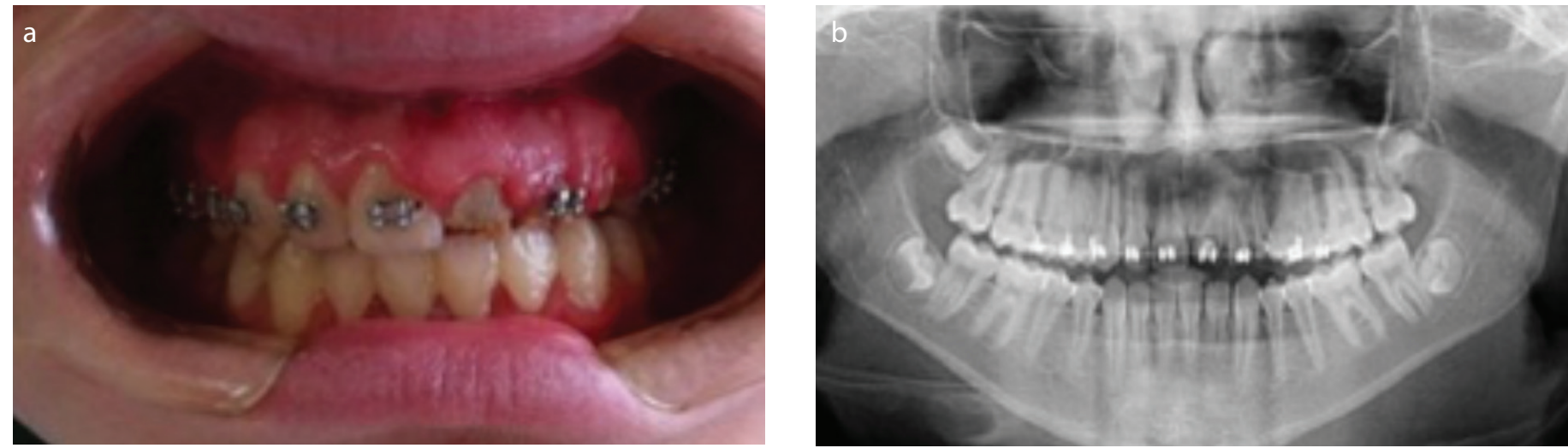

Figure 4. a, b. (a) Intraoral (b) radiographic view during orthodontic treatment.

the patient. It was learned from the mother that the patient's primary teeth were normal and exfoliated on time.

The patient showed normal maxillary dentition for her age during intraoral examination. The gingiva was enlarged, fibrous, and tense in the affected area. Permanent maxillary left central, lateral, and both canine teeth were unerupted. No dental abscess was seen clinically. All other teeth in the maxilla and mandible were normal. Radiographically, development of the maxillary left incisors and canine teeth was delayed, and these teeth showed abnormally formed and shortened roots, with a ghostlike appearance due to their reduced radiodensity (Figure 1).

After written informed consent was obtained from family, ROD was diagnosed and without extraction, a temporary prosthetic rehabilitation was applied (Figure 2). In order to keep track of the development of dentition and craniofacial growth, a periodic recall was offered.

The patient had periodontal surgery in the affected teeth after 3 years of temporary prosthetic rehabilitation follow-up. The teeth were misshapen, pitted, hypoplastic, and yellow or yellowish brown (Figure 3 ).

The teeth (\#21, \#22, \#23) showed abnormal eruption and root development. Orthodontic treatment was planned for tooth positioning. Brackets were applied to maxillary teeth for forced eruption and levelling for a period of 2 years (Figure 4). Periodontal surgery was then applied during levelling procedures.

When the patient was 11 years and 5 months old, root canal treatment was begun due to the apical lesions. A calcium hydroxide paste was applied to the teeth for reinstrumentation and redressing. After the removal of the intracanal dressing af- 

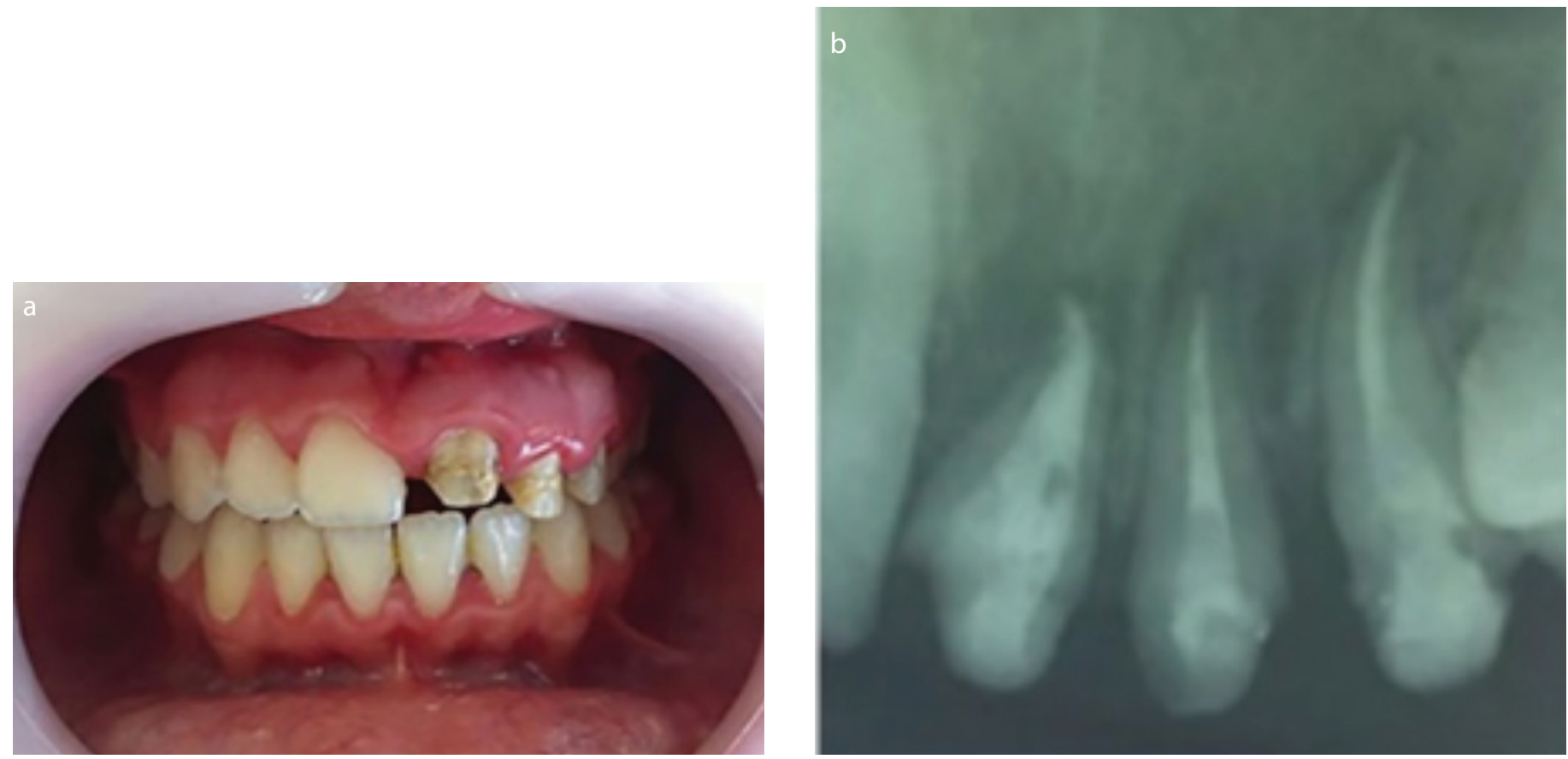

Figure 5. a, b. (a) Intraoral (b) radiographic view after endodontic treatment and post-core application.
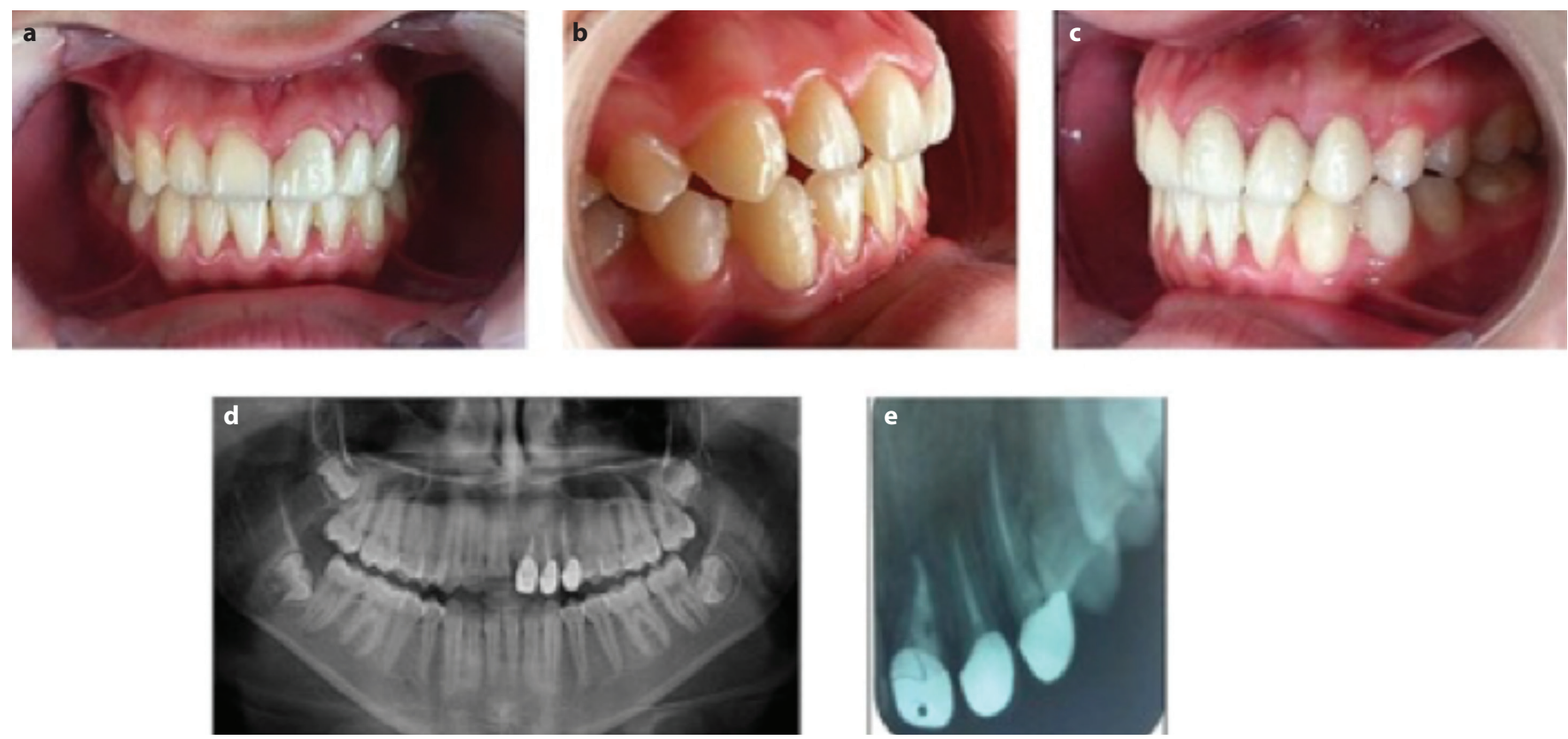

Figure 6. a-e. (a-c) Intraoral (d, e) radiographic view after zirconium crown in 5 year follow-up.

ter 1 year, ProRoot MTA (Dentsply-Maillefer, Ballaigues, Switzerland) was used as an apical plug. Intracanal fiber posts were selected considering the diameter of each canal. Composite resin restorations were used for the access cavity as a core (Figure 5). Each tooth was treated with a separate zirconium crown.

At the end of 10 years of treatment, the teeth presented no signs of external root resorption. Crowns compatible with gum and periodontal tissue were normal in color and shape (Figure 6).

\section{Discussion}

Approximately 200 cases have been reported in the literature regarding ROD. These articles describe the clinical, radiographic, and histological features of ROD as well as treatment alternatives.
For instance, endodontic approaches are considered conservative, while prosthetic rehabilitation is a less-conservative alternative. A fixed restorative prosthesis might be used in less affected patients, while patients with more severe cases must wait for the placement of implants or the final prosthetic reconstructions. Therefore, in more severe cases, extraction and removable temporary prostheses are more favorable $(4,6)$.

Canela et al. (11) presented a regional odontodysplasia case which occurred in the maxilla of a 10-month-old. After radiographic examination, the diagnosis was confirmed and follow-up went on for 5 years. Canela et al. (11) case supports the theory that an early diagnosis is critical to be able to determine the most convenient moment to intervene as well as to follow up and monitor ROD. 
Gondim et al. (3) reported a case of a 2.5-year-old patient. There was a fistula in the related area of the central incisor apex, which caused damage in the crowns of the right central and lateral incisors. The partially erupted right canine was healthy and hypoplastic. Initially, the maxillary right incisors underwent endodontic treatment, thus a conservative approach was adopted. The maxillary right incisors were then cleared from the radicular remnants. Prophylaxis was used as a treatment for the canine, and professional fluoride was applied topically at monthly follow-ups (3).

Babu et al. (1) presented a delayed eruption of teeth in the mandible of a 33-month-old boy. Intraoral examination revealed an adequate maxillary arch with fully erupted primary teeth. All the maxillary teeth appeared normal. Although all the primary teeth were visible in the mandibular arch, they were not fully erupted and seemed to be embedded in abnormal, slightly hyperplastic alveolar mucosa. Furthermore, these teeth revealed abnormal crown morphology with yellowish discoloration and hypoplastic enamel. Radiographically in the mandibular arch, all the primary teeth showed a striking "ghost-like" appearance. The treatment plan for the child was mainly conservative. Maintenance of proper oral hygiene and regular follow-up examinations for monitoring the developing dentition was advised (1).

Mukhopadhyay et al. (2) reported a 31/2-year-old girl with a chief complaint of noneruption of maxillary teeth. Extraoral examination of the patient showed a bilaterally symmetrical face. On intraoral examination, the patient presented with primary dentition. On the left quadrant of the maxilla, a hypoplastic, partially erupted primary central incisor and the tip of the adjacent lateral incisor were seen. As the condition was asymptomatic, a conservative treatment approach was followed (2).

An 8-year-old male from Turkey presented with a yellowish-brown color of the permanent canine tooth on the right maxilla. There was no indication of gingival swelling or abscess formation in the unerupted maxillary right permanent central incisor. In contrast to the unaffected teeth, in the radiographs, radiodentisity was lowered in the maxillary right deciduous canine tooth and germs of the maxillary right permanent central, lateral, and canine teeth. The extraction of maxillary right permanent central and canine teeth was performed, and an acrylic partial denture was used to rehabilitate the affected quadrant (12).

Gurunathan et al. (10) reported an RO case in an 111/2-yearold with condition of noneruption of the maxillary right permanent incisor. At 1-2 years old, the child had trauma to the maxillary anterior region. Generally, this tooth abnormality affects teeth in a single quadrant. The posterior teeth are less influenced than central and lateral incisors, along the midline or with possible involvement of each tooth (10). Likewise Ramakrishnan and Menon (14) presented a case with RO in involving single tooth, the maxillary right central incisor, which showed a ghost-like appearance. The patient's mother gave a history of intrusive trauma to the maxillary anterior region at 2 years old, and the history of extraction of the corresponding primary tooth (14).

Thimma Reddy et al. (15) reported a case with $\mathrm{RO}$ in the entire maxillary right quadrant. A temporary partial acrylic denture was used for rehabilitation, and periodic recalls followed treatment. After extraction was performed, dental implants were used for rehabilitation $(15,16)$. A similar case was in the right maxillary quadrant and left maxillary central incisor, which were affected by RO. The treatment was planned to follow the eruption process (17).

The progress of the development of teeth are described in many articles involving transplantation. However, orthodontic treatment such as autotransplantation of a mature tooth has been reported in few cases. The reviewed case is a rare one in that regards odontodysplasia as affecting only a single tooth.

Arx et al. (5) reported a case with $\mathrm{RO}$ in left mandible for a 6-year follow-up. In the treatment plan, the patient was given general anesthesia and underwent surgery to remove the primary molars, the permanent canine, premolars, and first and second molars of the right mandible. Immediately following, autotransplantation of the first premolars of the three other quadrants was done in the right mandible. Despite being affected by RO as well, the incisors that erupted fully were not extracted. This aggressive treatment approach was chosen due to recurrent infections (5).

An uncommon case of RO involving three quadrants of the jaws was reported. An 8-year-old boy had no history of hereditary anomaly in his family. Intraorally, the crowns of the maxillary and mandibular right permanent first molars were hypoplastic. The anterior region of the mandible was affected, and gingival overgrowth was observed. The maxillary and mandibular permanent molars and the mandibular permanent incisors were submitted to endodontic treatment. Prosthetic restoration will be performed after their eruption (18). Badger (19) presented a case with RO in maxillary left second primary molar. All these authors planned the treatment of RO by following long-term follow-up of tooth development.

There is an ongoing controversy regarding the treatment of ROD. ROD cases require constant and multidisciplinary treatment approaches. Many clinicians support the idea of removing the tooth affected by ROD immediately and placing a prosthetic replacement. Restorative procedures are preferred by some other clinicians so as to preserve the affected erupted teeth. In this present case, the affected teeth demonstrated most of the distinctive features of ghost teeth as characterized in the literature, both clinically and radiographically. The treatment was planned according to the age of the case, the development of the teeth, and the aesthetic need. A longterm follow-up after tooth development with orthodontic, endodontic, periodontal, and restorative treatments were performed. The development of root has been found to have been affected by orthodontic treatment forces and periodontal treatment.

\section{Conclusion}

There are some factors to consider in determining the best treatment option for ROD; whether it is an early diagnosis, what the present symptoms and signs consist of, what the functional and esthetic needs of the patient are, and which treatment modalities are available. A delay or failure in the process of tooth eruption may be caused by the noneruption of the affected teeth. Additionally, structural defects and the 
bacterial infection may often be seen as well. The age of the patient, the degree of anomaly, and the functional and esthetical needs of an individual case should all be taken into consideration when treatment plan is discussed. In addition to all, treatment of ROD requires a multidisciplinary approach.

Informed Consent: Written informed consent was obtained from the parents of the patient and patient who participated in this study.

Peer-review: Externally peer-reviewed.

Author Contributions: MK designed the study. KD and KG generated the data. FS and KD gathered the data. FS, KD and KG analyzed the data. MK and DY wrote the majority of the original draft. All authors approved the final version of the paper.

Acknowledgements: We would like to thank to family for the participation and sharing of information in this article.

Conflict of Interest: The authors have no conflicts of interest to declare.

Financial Disclosure: The authors declared that this study has received no financial support.

Türkçe öz: Rejyonel odontodisplazi tedavisi: 10 yıllık olgu takibi ve kaynak derlemesi. Bu makalenin amaci bir rejyonel odontodisplazi (ROD) olgusunun klinik ve radyografik özelliklerini sunmak ve bu konu ile ilgili güncel kaynakları derlemektir. 6 yaşındaki kız hasta üst çene sürekli orta kesici, yan kesici ve kanin dişilerindeki sürme problemleri ve bu dişlerin eksikliği şikayetleri ile kliniğimize başvurmuştur. Klinik muayenede etkilenen bölgede dişetinin büyümüş, fibröz ve gergin olduğu izlenmiştir. Radyografik muayenede kısa köklü anormal şekilli dişler izlenmiştir. Hasta geçici protez ile 3 yıl takip edildikten sonra periodontal cerrahi uygulanmıştır. Dişlerin sürdürülmesi ve ortodontik olarak sıralanmasını takiben anormal diş sürmesi ve anormal kök gelişimi izlenmiştir. ProRoot MTA (Dentsply-Maillefer, Ballaigues, Switzerland) materyali ile kök kanal tedavisi sonrası fiber post seçilmiş ve zirkonyum seramik kuronlar uygulanmıştır. ROD olgularında en uygun tedavi yaklaşımını seçmek için tanı zamanı, mevcut belirtiler ve hastanın işlevsel ya da estetik gereksinimleri değerlendirilmelidir. Anahtar kelimeler: Rejyonel odontodisplazi; hayalet dişler; diş sürmesi; Shell dişler; gelişimsel anomali

\section{References}

1. Babu NS, Smriti RJ, Pratima DB. Regional odontodysplasia: Report of an unusual case involving mandibular arch. Contemp Clin Dent 2015; 6: 237-9. [CrossRef]

2. Mukhopadhyay S, Roy P, Halder M. Regional odontodysplasia in the primary dentition associated with eruption failure. Int J Health Allied Sci 2016; 5: 195-7. [CrossRef]
3. Gondim JO, Pretel H, Ramalho LT, Santos-Pinto LA, Giro EM. Regional odontodysplasia in early childhood: A clinical and histological study. J Indian Soc Pedod Prev Dent 2009; 27: 175-8. [CrossRef]

4. Alotaibi ON. Regional odontodysplasia: An overeview. Pakistan Oral \& Dental Journal 2015; 35: 175-8.

5. von Arx T. Autotransplantation for treatment of regional odontodysplasia. Case report with 6-year follow-up. Oral Surg Oral Med Oral Pathol Oral Radiol Endod 1998; 85: 304-7. [CrossRef]

6. Ziegler S, Neukam FW. Regional odontodysplasia: Orthodontic treatment and transplantation of premolars. Am J Orthod Dentofacial Orthop 2012; 142: 710-9. [CrossRef]

7. Ibrahim Mostafa M, Samir Taha N, Ismail Mehrez MA. Generalised versus regional odontodysplasia: Diagnosis, transitional management and long term follow-up: A report of 2 cases. Case Rep Dent 2013; 1-5. [CrossRef]

8. Al-Tuwirqi A, Lambie D, Seow WK. Regional odontodysplasia: Literature review and report of an unusual case located in the mandible. Pediatr Dent 2014; 36: 62-7.

9. Cho SY. Conservative management of regional odontodysplasia: Case report. J Can Dent Assoc 2006; 72: 735-8.

10. Gurunathan D, Tandon S, Krishnan RR, Kalra M. Solitary odontodysplasia: A rare entity. J Indian Soc Pedod Prev Dent 2011; 29: S56-60. [CrossRef]

11. Canela AH, Rezende KM, Benitez M, Bonecker M. Early diagnosis of regional odontodysplasia in an infant. J Craniofac Surg 2012; 23: e134-6. [CrossRef]

12. Gunduz K, Zengin Z, Celenk P, Ozden B, Kurt M, Gunhan O. Regional odontodysplasia of the deciduous and permanent teeth associated with eruption disorders: A case report. Med Oral Patol Oral Cir Bucal 2008; 13: E563-6.

13. Courson F, Bdeoui F, Danan M, Degrange M, Gogly B. Regional odontodysplasia: Expression of matrix metalloproteinases and their natural inhibitors. Oral Surg Oral Med Oral Pathol Oral Radiol Endod 2003; 95: 60-6. [CrossRef]

14. Ramakrishnan M, Menon P. Odontodysplasia involving single tooth: A rare entity. SRM Journal of Research in Dental Sciences 2014; 5: 140-2. [CrossRef]

15. Thimma Reddy BV, Vinay Reddy KK, Sunil B, Pujita R, Kiran K, Kranthi KR. Regional odontodysplasia. J Indian Soc Pedod Prev Dent 2010; 28: 315-8. [CrossRef]

16. Mehta DN, Bailoor D, Patel B. Regional odontodysplasia. J Indian Soc Pedod Prev Dent 2011; 29: 323-6. [CrossRef]

17. Upadhyay V, Chaturvedi TP, Pandey RK, Chaurasia A, Singh P. Regional odontodysplasia crossing midline: $A$ rare case report. Int J Clin Pediatr Dent 2011; 4: 159-61. [CrossRef]

18. Quindere LB, Cavalcante RB, Nonaka CF, Miguel MC, de Souza LB. Regional odontodysplasia involving three quadrants of the jaws: A case report. Quintessence Int 2010; 41: 13-6.

19. Badger GR. Regional odontodysplasia-an unusual development. J Dent Health Cosmesis 2016; 1: 1-4. [CrossRef] 